Sian Troath | Prospects for Australian-Led Regional Cooperation on Asylum Seeker and Refugee Issues

Prospects for Australian-Led Regional Cooperation On Asylum Seeker and Refugee Issues

\author{
Sian Troath" \\ troa0001@flinders.edu.au
}

\begin{abstract}
The nomination of former Refugee High Commissioner Antonio Guterres for Secretary-General, the ongoing and intensifying condemnations of Australia's offshore detention centres on human rights grounds, and the ruling of the Papua New Guinea Supreme Court regarding detention centres on Manus Island, indicate that the Australian government needs a new policy on asylum-seekers. The domestic political demand for a deterrence-based, "no advantage", tough on borders approach means that the only way to achieve this would be through regional cooperation, which would be impossible without the cooperation of Indonesia. Analysing why there is such strong involvement of domestic politics on this issue, even to the detriment of the bilateral relationship with Indonesia, is vital to understanding how to improve the relationship and foster regional cooperation on asylum seekers. While reaching a broad cooperative agreement on asylum seekers in general would be far too difficult, the Rohingya refugee crisis presents a specific case on which regional cooperation could be built. If successful, this would serve as a building-block for deeper and more sustained regional cooperation on asylum seekers.
\end{abstract}

Keyword:Key Words: Australia, Indonesia, asylum seekers, cooperation

*Flinders University

Andalas Journal of International Studies | Vol 5 No 2 November Tahun 2016 | 108 


\section{Sian Troath | Prospects for Australian-Led Regional Cooperation on Asylum Seeker and Refugee Issues}

\section{Introduction}

There is a number of refugee crises taking place across the world, and yet cooperation on such issues remains fraught with difficulties. The most notable, of course, is the Syrian refugee crisis, which is a point of concern for states all the way through from neighbouring Middle Eastern states to Europe, the United States, and even Australia. The Syrian case is a perfect example of how enmeshed refugee issues are with both domestic and international politics, well beyond any humanitarian or resource-based concerns. Despite an increasingly intertwined and globalised world, refugees and asylum seekers remain one of the key transnational issues states struggle to resolve through cooperative means. As Alexander Betts points out, examining why this is the case is not only important for the protection of human rights, it also presents an interesting area of study for international relations. ${ }^{1}$ This essay will focus on Australia's position on refugees and in particular asylum-seeker arrivals by boat, examining how this position impacts on the possibilities for regional cooperation. In particular, this essay will explore the prospects for cooperation between Australia and

\footnotetext{
${ }^{1}$ Alexander Betts, Protection by Persuasion: International Cooperation in the Refugee Regime, (USA: Cornell University Press, 2009), 2.
}

Indonesia, and the potential for the Rohingya refugee issue to serve as a building-block in fostering broader cooperation on asylum seekers. Australia and Indonesia are two of the most significant middle powers in the region, which means they are the states with the greatest means to play leading roles on regional issues. This is particularly fortuitous given their complementary roles within the refugee regime, with Australia being a traditional refugee recipient, and Indonesia being a traditional transit country for asylum seekers attempting to reach Australia. As Betts argues, refugee issues can often be framed in terms of a North-South impasse, ${ }^{2}$ which is certainly the case in this scenario. This argument is strengthened by Susan Kneebone, who discusses the unlikelihood of Southeast Asian states taking the lead on cooperation regarding refugee and asylum seeker issues. ${ }^{3}$ With regards to the recent Rohingya refugee crisis, she argues that "either ASEAN collectively needs to act decisively to tackle the source of the Rohingya issue, and/or Australia needs to 'step up to the mark' and accept its ethical responsibility, something which could also

\footnotetext{
${ }^{2}$ Betts, 3 .

${ }^{3}$ Susan Kneebone, "Comparative Regional Protection Frameworks for Refugees: Norms and Norm Entrepreneurs"'The International Journal of Human Rights 20, no. 2(2016): 166.
} 


\section{Sian Troath | Prospects for Australian-Led Regional Cooperation on Asylum Seeker and Refugee Issues}

be applied to Australia's responsibility towards asylum seekers in general. ${ }^{4}$ As Indonesia is the "engine of ASEAN", clearly Indonesia and Australia are the two key states to focus on when discussing the potential for regional cooperation on refugee and asylum seeker matters, and the Australia-Indonesia bilateral relationship is one of the utmost importance. As Hunt argues, there is no regional solution that is possible without the support of Indonesia. ${ }^{6}$ While the Indonesia-Australia relationship is clearly the primary bilateral relationship to focus on and grounds exist on which cooperation can be built, beginning with any kind of broad-based, generalised agreement on asylum seekers would be a big ask. This is where the Rohingya case could be used as a building block on which further cooperation could be built, centred around the Australia-Indonesia bilateral relationship but also capable of drawing in other ASEAN states. Amidst growing condemnations of Australia's offshore detention policy due to human rights concerns, and the ongoing disintegration of the use of Manus Island as an offshore detention location, the Australian government desperately needs a change in

\footnotetext{
${ }^{4}$ Ibid.

${ }^{5}$ BrunoHellendorff and Manuel Schmitz, "Indonesia: From Regional to Global Power?",GRIP Analysis(7 May 2014): 2.

${ }^{6}$ LukeHunt, 'Indonesia Watch', The Diplomat (May 172011):http://thediplomat.com/2011/05/ind onesia-watch/(accessed 28/02/2015).
}

policy which can be marketed simultaneously as a win for human rights and as a continuation of a deterrencebased, "no-advantage", tough on borders approach. The only way to achieve such a goal is through regional cooperation. This paper will explore the domestic context for Australia's need for this type of policy, the effect the domestic political needs for such a policy has had on Australia's relationship with Indonesia, and the possibilities for establishing regional cooperation on asylum seeker and refugee issues in the future, with particular reference to the potential the Rohingya refugee crisis has to serve as a building block for further cooperation.

\section{What Promotes International Cooperation on Asylum Seekers?}

Alexander Betts discusses the factors which have promoted key instances of past cooperation on refugee and asylum seeker issues, which provide a valuable starting point for understanding the context in which cooperation is likely. In his book Protection by Persuasion: International Cooperation in the Refugee Regime Betts provides a number of useful arguments. Most notably he argues that there needs to be more to a state's commitment to cooperation on asylum seeker policy than pure humanitarian concerns, that individuals in positions of power can play 


\section{Sian Troath | Prospects for Australian-Led Regional Cooperation on Asylum Seeker and Refugee Issues}

key roles in promoting cooperation, and that states need to be sure that the burdensharing they are taking place in will be reciprocated to a satisfactory degree. ${ }^{7}$ The first is apparent in the case of Australia, as the widespread concern regarding irregular maritime arrivals means that Australia should have an interest in seeking an effective burden-sharing arrangement and promoting regional cooperation on asylum seekers. Given the domestic salience of the issue and the potential collapse of the offshore detention arrangement with Papua New Guinea, there is perhaps more incentive at present to find alternatives to the current policy. Similarly regarding the prospects for key individuals to promote cooperation through individual agency, the appointment of Antonio Guterres as United Nations Secretary General, known for his ten-year stint as Refugee High Commissioner, ${ }^{8}$ certainly holds promise. One of the key difficulties, therefore, is the need for states to have confidence that burden-sharing will be reciprocal to the degree they require. This is due to fear and uncertainty regarding other states' intentions which results in concerns that burden-sharing will not be reciprocated. Consequently, bilateral and regional

${ }^{7}$ Betts.30, 46 .

${ }^{8}$ Author not specified, "Who is Antonio Guterres? Meet the UN's Next Secretary-General", $B B C$ News (6 October 2016): www.bbc.com/news/world-europe37565570 (accessed 19 October 2016). relationships need to be improved before wide-scale cooperation can take place. A building-block approach to furthering trust and cooperation is of particular use here. ${ }^{9}$ A building-block approach involves understanding that cooperating on lowlevel issues helps to build confidence and trust between states, creating a basis on which further cooperation on higher-level issues can be undertaken.Although broad regional cooperation on asylum seeker issues would be most beneficial to Australia, this article will focus primarily on the prospects for building such cooperation with Indonesia, and specifically with regards to the Rohingya refugee crisis. This will also serve to illustrate the importance of understanding the particularities of a bilateral relationship when seeking to promote cooperation between those states.

\section{Australia's Approach to Asylum Seekers}

In recent years Australia's policies of offshore detention and third-party settlement have become problematic thorns in its regional relationships. It is therefore important to understand why Australia has proceeded with policies

\footnotetext{
${ }^{9} \mathrm{An}$ approach most often used with regards to Maritime Confidence Building Measures. See, for example, Sam Bateman 'Maritime Confidence Building Measures - An Overview', in Maritime Confidence Building Measures in the South China Sea, ASPI Special Report (September 2013): 7-13.
} 


\section{Sian Troath | Prospects for Australian-Led Regional Cooperation on Asylum Seeker and Refugee Issues}

which cause such unrest with its neighbours, as well as drawing condemnation from the United Nations. ${ }^{10}$ This section will explore the driving factors behind Australia's policies toward asylum seekers, beginning with the Howard government.

Asylum seeker policies underwent a significant change during the Howard era as the issue gained prominence in the public eye following the arrival of higher numbers of asylum seekers within the context of the War on Terror. Beginning with this "third wave" of asylum seekers to Australia hailing primarily from the Middle East, there was a clear increase in hostility toward asylum seekers by the media, politicians, and the public. ${ }^{11}$ Linked with this has been the overwhelming domination of asylum seeker policy by domestic political concerns. The international context following the September 11 terrorist attacks was undeniably a considerable factor in this process, but the key element to these changes has been how this event and the

${ }^{10}$ Author not specified, "Who is Antonio Guterres? Meet the UN's Next SecretaryGeneral", $B B C \quad$ News $\quad(6 \quad$ October 2016):www.bbc.com/news/world-europe37565570 (accessed 19 October 2016).

${ }^{11}$ Fiona H. McKay, Samantha L. Thomas, and Warwick Blood, "'Any One of These Boat People Could Be A Terrorist For All We Know!' Media Representations and Public Perceptions of 'Boat People' Arrivals in Australia”, Journalism 12, no. 5(2011): 609. subsequent war on terror have been absorbed and understood domestically. McKay argues that the September 11 terrorist attacks led to a conflation of people smuggling and terrorism, and the xenophobia this inflamed was then able to be manipulated by the media and by politicians. $^{12}$ As argued by Burke, conflating the issues of terrorism and asylum seekers "was central to a domestic politics of identity and intimidation designed to transform Western societies in ways that encourages xenophobia and consent for coercive and extra-legal policy approaches". ${ }^{13}$ In fact, Perera goes so far as to describe this as the space where the "'war on terrorism' meets the 'war at home"". ${ }^{14}$ This process by which asylumseeker policies became so high profile and so intrinsically linked to domestic politics created a situation in which effective deterrence-based asylum-seeker policies became one of the main measures of the competence of the Australian government. ${ }^{15}$ As a consequence of this

\footnotetext{
${ }^{12}$ See FionaMcKay, 'A Return to the 'Pacific Solution', Forced Migration Review 44 (2013): 24-26.

${ }^{13}$ Anthony Burke, Fear of Security: Australia's Invasion Anxiety (Melbourne: Cambridge University Press, 2008), 177.

14 SuvendriniPerera, "What is a Camp?",Borderlands E-journal 1, no. 1(2002).http://www.borderlands.net.au/voll no1_2002/perera_camp.html (accessed 28/02/2015).

15 MichaelGrewcock, "Back to the Future: Australian Border Policing Under Labor,
} 


\section{Sian Troath | Prospects for Australian-Led Regional Cooperation on Asylum Seeker and Refugee Issues}

process by which asylum seeker policies became increasingly embedded in domestic politics, foreign policy interests, and in particular good relations with Indonesia, were often sacrificed for the purpose of domestic political gain.

A number of policy changes took place over the course of the Rudd-Gillard government, in no small part fueled by the domestic response to growing arrival numbers of asylum seekers reaching Australia by boat. While the Rudd government began to dismantle the Pacific Solution following their election in 2007 , the rise in asylum seeker arrival numbers following this policy change brought the issue back into the public spotlight. ${ }^{16}$ Consequently, by the time Julia Gillard had taken over leadership of the Labour Party in 2010, asylum seekers had become a major electoral issue, in a way that had not been seen since 2001. ${ }^{17}$ Despite the initial shift in 2007 which involved the dismantling of the Howard government's Pacific Solution, under Gillard asylum seeker policy became increasingly harsh as

2007-2013", State Crime Journal 3, no. 1(2014): 103

${ }^{16}$ With numbers jumping from 161 in 2008 , to 2849 in 2009 and 6879 in 2010. See Janet Phillips and Harriet Spinks, "Boat Arrivals in Australia Since 1976", Australian Parliamentary Library (2013): 18.

17 MattMcDonald, "Deliberation and Resecuritization: Australia, Asylum-Seekers and the Normative Limits of the Copenhagen School", Australian Journal of Political Science 46, no. 2(2011): 281. the domestic focus of the issue once again meant that the competence of the government was measured by their ability to control irregular maritime arrivals. This meant that by the time the 2013 election took place, Woolner argues that the Liberal policy to turn boats back to Indonesia was the only significant policy difference between the two major parties. ${ }^{18}$ Although under Gillard there was an attempt to shift the discourse on asylum seekers from demonising asylum seekers to demonising people smugglers, Pickering and Weber argue that many politicians continued to focus on asylum seekers as a source of threat to Australian national identity. ${ }^{19}$ Once again as during the Howard era, and as continues today, "the Australian identity . . . constructed as dominant and 'good', contrasted against the foreign and 'bad other', the asylum seeker arriving by boat". ${ }^{20}$ Due to the strong domestic demands for action on this issue Gillard needed to simultaneously meet these expectations and justify the

\footnotetext{
${ }^{18}$ Derek Woolner, "When No Means No: Indonesia and Tony Abbott's Asylum Boat Policy", Dissent (Spring 2013): 28.

19 SharonPickering, and Leanne Weber, "New Deterrence Scripts in Australia's Rejuvenated Offshore Detention regime for Asylum Seekers", Law \& Social Inquiry 39, no. 4(2014): 1009 .

${ }^{20}$ ElizabethRowe and ErinO'Brien, "'Genuine' Refugees or Illegitimate 'Boat People': Political Constructions of Asylum Seekers and Refugees in the Malaysia Deal Debate", Australian Journal of Social Science 49, no. 2(2014): 176 .
} 


\section{Sian Troath | Prospects for Australian-Led Regional Cooperation on Asylum Seeker and Refugee Issues}

need for having such expectations. This process, fueled by portrayals of asylum seekers both by the media and politicians, meant that the way in which the asylum seeker issue was framed resulted in a legitimisation of public fears that asylum seekers posed a genuine threat to Australian national identity and security. ${ }^{21}$ This is seen, for example, in her statement that "expressing a desire for a clear and firm policy to deal with a very difficult problem does not make you a racist". ${ }^{22}$ Justifying the need for asylum seekers to be discussed in terms of national security contributes to the nature of nationalistic concerns regarding asylum seekers, heightening the importance of the issue and resulting in a prioritisation of populist domestic policies over foreign policy considerations.

The Abbott period saw an intensification of the harshness of asylum seeker policy take place, as the conflation of asylum seekers and terrorism continued and fear and xenophobia were exacerbated. The election of the Abbott government in 2013 was in no small part due to Abbott's

${ }^{21}$ McDonald, 290.

${ }^{22}$ Author not specified, "Julia Gillard's Speech to the Lowy Institute on Labor's New AsylumSeeker Policy for Australia",The Australian(July 72010) :http://www.theaustralian.com.au/archive/po litics/julia-gillards-speech-to-the-lowyinstitute-on-labors-new-asylum-seekerpolicy-for-australia/story-e6frgczf1225888445622 (accessed 28/02/2015). platform and rhetoric on asylum seekers, ${ }^{23}$ most notably his 'turn back the boats' policy. ${ }^{24}$ As the September 11 terrorist attacks and the U.S. led War on Terror played a significant role in the discourse on asylum seekers during the Howard period, so too did the growth of ISIS play a significant role during the Abbott government. Subsequently, during the Abbott government period asylum seekers were at various times explicitly linked to potential threats of terrorism, and as had been seen throughout previous governments the willingness of asylum seekers to effectively integrate in Australia and uphold Australian values was questioned. ${ }^{25}$ These portrayals and understandings of asylum seekers are hardly new. Although the particulars have changed with the times, Burke argues that the securitization of asylum seekers under the Abbott government was merely "the latest reiteration of overarching security discourses that have long defined modern Australia". ${ }^{26}$ Understanding the deeper historical context of Australian asylum seeker policies is important, as it allows us

\footnotetext{
${ }^{23}$ Christopher C. White, “Australia's Boatpeople Policy: Regional Cooperation or Passing the Buck?",Cultural Encounters, Conflicts, and Resolutions 1, no. 1(2014): 14.

24 JimDella-Giacoma, "Different Pond, Different Fish: Crossed Wires in AustralianIndonesian Relations",Kill Your Darlings 17 (2014): 9.

${ }^{25}$ McDonald, 288.

${ }^{26}$ Burke, quoted in McDonald, 284.
} 


\section{Sian Troath | Prospects for Australian-Led Regional Cooperation on Asylum Seeker and Refugee Issues}

to take into account long-standing understandings and experiences of Australian sovereignty and national identity and how they play out in the current context. This again highlights the extent to which government policies toward asylum seekers have been motivated by their domestic audience, and explains why policies have been enacted which are problematic for foreign policy concerns, and in particular regional bilateral relationships.

\section{The Australia-Indonesia Relationship in the Context of Asylum Seekers}

The issue of asylum seekers arriving in Australia by boat has, at various times, become a significant issue for the Australia-Indonesia relationship, given that such boat arrivals often use Indonesia as a transit country. For the Australia-Indonesia relationship, the issue of asylum seekers highlights a number of factors which often impede good relations between the two states, including state identity, sovereignty, and domestic politics. This section will discuss how these factors affect the bilateral relationship by examining key incidents of cooperation and key incidents of tension.

Responses to asylum seekers during the Howard era began a trend of pushing responsibility for asylum seekers onto Indonesia, a trend which has continued through to the present day and on a number of occasions has extended to a blatant disregard for Indonesian sovereignty. Under the Howard government, the most notable incident to take place in the context of AustraliaIndonesia relations was the Tampa affair. This incident involved the arrival of a Norwegian freighter, the $M V$ Tampa, in August 2001, following its rescue of 438 asylum seekers from a sinking ship seeking to land at Christmas Island. ${ }^{27}$ The government, backed by the Labour opposition, refused Captain Rinnan and the Tampa entry. ${ }^{28}$ As the sinking ship had embarked from Indonesia, the government viewed its passengers as Indonesia's responsibility, as illustrated by John Howard's failed attempt to contact Indonesian President Megawati Sukarnoputri regarding the incident. ${ }^{29}$ Woolner argues that it has been apparent since this incident that Australian politicians generally do not show sensitivity toward Indonesian views, and that this lack of sensitivity has negative consequences for Australia's capability to

\footnotetext{
${ }^{27}$ McKay, Thomas, and Blood, 609.

${ }^{28}$ Katharine Betts, "Boatpeople and Public Opinion in Australia", People and Place 9, no. 4(2001): 39

${ }^{29}$ Susan Kneebone, and Sharon Pickering, "Australia, Indonesia and the Pacific Plan", in New Regionalism an Asylum Seekers: Challenges Ahead,ed. Susan Kneebone and Felicity Rawlings-Sanei(Oxford and New York: Berghahn Books, 2007), 173-4.
} 


\section{Sian Troath | Prospects for Australian-Led Regional Cooperation on Asylum Seeker and Refugee Issues}

foster regional cooperation on asylum seeker policies. ${ }^{30}$ Despite the unease this lack of sensitivity has caused on various occasions, Indonesia is aware of the high priority the Australian government places on asylum seeker policies, and has been willing to cooperate on the issue in the past in order to maintain a good bilateral relationship. ${ }^{31}$ What was required for such cooperation to take place was the provision of capacity building assistance to Indonesia, and Australian respect for Indonesian sovereignty. ${ }^{32}$ This is seen, for example, in the two bilateral agreements made between Indonesia in 2000 and 2007, the Regional Cooperation Arrangement, and the Management and Care of Irregular Immigrants Project. ${ }^{33}$ The first was an arrangement under which Indonesia would intercept asylum seekers and refer them to the IOM, while the second included measures such as the renovation of Immigration Detention Houses in Indonesia. ${ }^{34}$ These agreements provide a perfect example of buildingblocks which had the potential to lead to further cooperation, had such cooperation been prioritised. Significant cooperation

${ }^{30}$ Woolner, 29.

31 AmyNethery, Brynna Rafferty-Brown, and Savitri Taylor, "Exporting Detention: Australia-Funded Immigration Detention in Indonesia", Journal of Refugee Studies 26, ${ }^{32}$ Ibid. no. 1 (2012): 94

${ }^{33}$ Nethery, Rafferty-Brown, and Taylor, 95.

${ }^{34}$ Nethery, Rafferty-Brown, and Taylor, 95-6. also took place regarding combating people smuggling syndicates, and it was cooperation on this issue which led to the establishment of the Bali Process on AsiaPacific Coordination Against People Smuggling and Trafficking in 2002 (the Bali Process). ${ }^{35}$ The Bali Process now forms the most useful multilateral forum for promoting cooperation on asylum seekers, argues Taylor, ${ }^{36}$ although according to Woolner the Bali Process has received only intermittent attention from Australia. ${ }^{37}$ While cooperation between Australia and Indonesia took place during this period, the tendency to prioritise domestic politics over the bilateral relationship and avoid responsibility for asylum seekers traveling to Australia by boat is certainly apparent.

Under the Rudd government a strong effort to cooperate with Indonesia on the issue of asylum seekers was undertaken, however (,) a continuation of the previous trends of disregarding Indonesian sensitivities and avoiding responsibility for asylum seekers made this difficult. Rudd's approach to asylum

\footnotetext{
${ }^{35}$ Woolner, 30.

36 Savitri Taylor, "Sharing Responsibility for Asylum Seekers and Refugees in the Asia Pacific Region" in Migration: The Ashgate Research Companion to Migration Law, Theory and Policy, ed. Satvinder S. Juss (Surrey: Ashgate Publishing Limited, 2013): 252.

${ }^{37}$ Woolner, 30.
} 


\section{Sian Troath | Prospects for Australian-Led Regional Cooperation on Asylum Seeker and Refugee Issues}

seekers was so heavily focused on

Indonesia it led Woolner to argue that "the

Rudd government sought to restrict to Indonesian territory so much of the problem that his approach was labelled 'Rudd's Indonesian solution"”, ${ }^{38}$ However, all hopes for any kind of "Indonesian solution" were dashed following the Oceanic Viking incident. ${ }^{39}$ This incident involved the rescue of asylum seekers from the Oceanic Viking from international waters within Indonesia's search and rescue area. ${ }^{40}$ Australia wished to return the asylum seekers to Indonesia, something which Taylor and RaffertyBrown argue highlighted the extent to which the benefits of border control cooperation were asymmetrically tilted in Australia's favour. ${ }^{41}$ Although this incident was tentatively resolved with the creation of a framework ${ }^{42}$ highlighting how to manage such situations, ${ }^{43}$ the trend of Australia deflecting responsibility for asylum seekers through the use of methods which, at best, upset Indonesian sensibilities, and at worst actively violated

\footnotetext{
${ }^{38}$ Woolner, 29.

${ }^{39}$ Woolner, 29.

40 SavitriTaylor and Brynna Rafferty-Brown, "Waiting for Life to Begin: the Plight of Asylum Seekers Caught by Australia's Indonesian Solution", International Journal of Refugee Law 22, no. 4(2010): 560.

${ }^{41}$ Taylor and Rafferty-Brown, 560-1.

42 The Implementation Framework on People Smuggling and Trafficking in Persons, signed 9 March 2010.

${ }^{43}$ Taylor and Rafferty-Brown, 590.
}

Indonesian sovereignty, continued. To begin with, the shift of the Rudd-Gillard government toward focusing primarily on people smugglers led to the detention of Indonesian boat crews. ${ }^{44}$ Concerns were raised by an Indonesian Foreign Ministry spokesman with regards to the delays in the trials of these individuals, and whether or not Australia was capable of differentiating between "the mostly impoverished fisherman who crewed the boats and the organisers of the people smuggling rings". ${ }^{45}$ Following this, further concerns were raised regarding Australia's respect for Indonesian sovereignty when Gillard proposed the creation of a regional processing centre in East Timor without consulting Indonesia on the matter prior to the announcement. ${ }^{46}$ This was particularly provocative given Australia's involvement in the independence of East Timor. Grewcock argues that such attempts as the East Timor regional processing centre, as well as the successful creation of agreements with Papua New Guinea and Nauru, can be seen as a form of neocolonialism. ${ }^{47}$ This is particularly true with regards to Papua New Guinea and Nauru given Australia's historical control or influence over the two states, and their

\footnotetext{
${ }^{44}$ Woolner, 30.

45 Ibid.

${ }^{46}$ Ibid.

${ }^{47}$ Michael Grewcock, "Australian Border Policing: Regional 'Solutions' and Neocolonialism", Race and Class 55, no. 3(2014): 75.
} 


\section{Sian Troath | Prospects for Australian-Led Regional Cooperation on Asylum Seeker and Refugee Issues}

dependence on Australian development aid. ${ }^{48}$ It is apparent that perceptions of Australia as an entitled developed country enacting policies which could easily be described as neo-colonial have greatly harmed Australia's reputation in the region, particularly with the nearby neighbours who would need to be key participants in any form of regional cooperation on asylum seekers and refugees.

The situation worsened under the leadership of the Abbott government, as the prioritisation of domestic politics and disregard for Indonesian sovereignty intensified. Perhaps more than those preceding him, Abbott's leadership was heavily reliant on his ability to prevent the arrival of asylum seekers by boat, given the extent to which his election campaign focused on the issue. The relationship with Indonesia was already tense during this period, following revelations that Australia had been spying on Indonesia, ${ }^{49}$ and Abbott's refusal to apologise. ${ }^{50}$ The policy

48 Ibid.

49 MichaelBachelard, and David Wroe, "ndonesia Recalls Ambassador to Australia Over Spying Claim", The Age (November 18 2013):http://www.theage.com.au/world/indo nesia-recalls-ambassador-to-australia-overspying-claim-20131118-2xrem.html (accessed 28/02/2015).

${ }^{50}$ Author not provided, "Abbott belittles Spying Row: SBY”, The Jakarta Post(November 19 2013): http://www.thejakartapost.com/news/2013/1 to turn back boats to Indonesia once again placed responsibility on Indonesia for the issue, however the willingness to violate Indonesian sovereignty to achieve this and the ironic naming of the policy Operation Sovereign Borders served only to exacerbate bilateral tensions ${ }^{51}$ Indonesian sovereignty was violated not only in the turning back of asylum seeker boats, but also through the addition of three passengers on one of the boats, ${ }^{52}$ and a number of accidental incursions of Indonesian territorial waters by Australian naval and customs vessels. ${ }^{53}$ Kevin argues that Australia pushed Indonesia to such a point where they felt it was necessary to state "we will not tolerate this any longer", ${ }^{54}$ following a diplomatic standoff over 56 asylum seekers in November 2013

1/19/abbott-belittles-spying-rowsby.html(accessed 28/02/2015)

${ }^{51}$ Della-Giacoma, 10-12.

52 EmmaGriffiths, "Indonesia Says Australia Alledgedly Adding Passenger to Asylum Seeker Boat a 'Serious Development"', $A B C$ News(May 2014):http://www.abc.net.au/news/2014-0506/marty-natalegawa-on-boat-extrapassengers-seriousdevelopment $/ 5434540$ (accessed 28/02/2015).

53 LatikaBourke, "Navy Breached Indonesian waters Six Times Under Operation Sovereign Borders, Review Finds", $A B C$ News(20 February 2014):http://www.abc.net.au/news/2014-0219/navy-breached-indonesian-waters-sixtimes-review-finds/5270478(accessed 28/02/2015).

${ }^{54}$ TonyKevin, "Mishandling Indonesia", Eureka Street 23, no. 22(2013): 16. 


\section{Sian Troath | Prospects for Australian-Led Regional Cooperation on Asylum Seeker and Refugee Issues}

during which Agus Barnas ${ }^{55}$ stated that Indonesia should not be a 'dumping ground' for asylum seekers. ${ }^{56}$ Despite Abbott's stated desire that he wanted his foreign policy to be 'more Jakarta and less Geneva', 57 the nature of his domestic political campaign and the response this generated among voters meant that an increasingly stringent policy toward asylum seekers attempting to reach Australia by boat was the only viable domestic political policy position he could take, regardless of the consequences for Australia-Indonesia relations. As ASEAN Chief Surin Pitsuwan stated, it was clear that many of Abbott's comments on the issue could only be seen as "internal rhetoric for internal consumption". 58 Pitsuwan also warned that Abbott's 'turn back the boats' policy was "counterproductive", and that pushing the responsibility for such issues onto Southeast Asian states was unwise, as such inherently transnational issues cannot be solved unilaterally. ${ }^{59}$ A vital step in

\footnotetext{
${ }^{55}$ Spokesman for Indonesian Coordinating Minister for Legal, Political and Security Affairs, Djoko Suyanto.

${ }^{56}$ Kevin, 16.

${ }^{57}$ Della-Giacoma, 9.

${ }^{58}$ Daniel Flitton, "Diplomat Rejects Abbott's TowBack Plan",The Sydney Morning Herald(October 24 2012):http://www.smh.com.au/opinion/polit ical-news/diplomat-rejects-abbotts-towbackplan-20121023283hp.html\#ixzz2ADhYwtq7 (accessed 28/02/2015).

${ }^{59}$ Ibid.
}

seeking a regional multilateral approach to asylum seeker and refugee issues will be ensuring a strong bilateral relationship between Australia and Indonesia.

\section{The Case of the Rohingya: A Building Block for Further Regional Cooperation?}

Establishing cooperation on asylum seekers broadly is likely too ambitious a starting point without some significant change in circumstances. A better approach would be a limited form of cooperation, one that can serve as a functional building block for promoting trust in effective and reciprocal burdensharing between the participating states, thus creating a stronger basis for further cooperation in the future. Although it does not present an easy case for cooperation, he Rohingya crisis does present the best opportunity for cooperation, particularly given its protracted nature:

One mechanism of regional cooperation might usefully focus on the plight of the longterm displaced. Its aim would be to resettle those who have been displaced for at least two years and who have no hope of escaping persecution and returning to their country safely. This mechanism could be piloted as part of existing resettlement programs in Australia, New Zealand and Japan, as a way of 


\section{Sian Troath | Prospects for Australian-Led Regional Cooperation on Asylum Seeker and Refugee Issues}

implementing the Bangkok

Principles on burden-sharing. ${ }^{60}$

Not for the first time, a refugee crisis involving Rohingya asylum seekers from Myanmar took place in early 2015, in which roughly 25, 000 Rohingya and Bangladeshi's attempted to seek refuge in Thailand. ${ }^{61}$ When Thailand began to push the refugees back to sea, they attempted to reach Malaysia and Indonesia instead, with many left stranded on boats. ${ }^{62}$ The reactions to these refugees provoked international outrage, including calls for ASEAN states to seek a cooperative solution to the crisis, ${ }^{63}$ and calls for Australia to step up and play a role in the crisis. ${ }^{64}$ It took some time for any form of cooperation to take place, with an initial meeting between Malaysia, Indonesia, and Thailand inducing the agreement of Malaysia and Indonesia to stop turning boats away, and a Special Meeting on Irregular Migration in the Indian Ocean being held with the attendance of twenty governments and international agencies. This resulted in agreement on a number of

\footnotetext{
${ }^{60}$ Joyce Chia, and Justice Susan Kenny, "The Children of Mae La: Reflections on Regional Refugee Cooperation", Melbourne Journal of International Law 13, no. 2(2012): 858.

${ }^{61}$ Carlyle A. Thayer, "Southeast Asia's Regional Autonomy Under Stress", Southeast Asian Affairs (2016).

${ }^{62}$ Ibid.

${ }^{63}$ Ibid.

${ }^{64}$ Kneebone, 166.
}

measures, although these were not comprehensive and certainly did not address the root causes of the refugee crisis, being "their stateless status and persecution within Myanmar". ${ }^{65}$ It is therefore likely that such a crisis will happen again, and having the potential for more comprehensive and responsive regional cooperation on the issue would be highly valuable. Ideally, cooperation would go one step further and work on processing Rohingya refugees already outside Myanmar, for example those in Thai-Burmese border camps or Thai immigration detention centres. ${ }^{66}$ As Slezak, Singer, and Ramadurai argue, "the international community must take concrete steps to share the responsibility of protecting the Rohingya". ${ }^{67}$ Thailand would need to be involved in a regional cooperative effort, as it is most commonly the country of first asylum. ${ }^{68}$ Indonesia and Malaysia, as the destination countries, ${ }^{69}$ would also need to be involved. Australia and New Zealand, as the two developed states in the region with a refugee resettlement programme, are

\footnotetext{
65 Thayer, "Southeast Asia's Regional Autonomy Under Stress".

${ }^{66}$ Amanda Crews Slezak, Thalia Roussos Singer, and Rupa Ramadurai, "Stateless and Fleeing Persecution: the Situation of the Rohingya in Thailand", Children's Legal Rights Journal 35, no. 1(2015): 46.

${ }^{67}$ Ibid.

${ }^{68}$ Slezak 48.

${ }^{69}$ Ibid.
} 


\section{Sian Troath | Prospects for Australian-Led Regional Cooperation on Asylum Seeker and Refugee Issues}

uniquely positioned to be leading forces in a regional effort to manage the current population of Rohingya in camps and detention centres outside Myanmar, and any future mass exoduses of Rohingya from Myanmar. As New Zealand has already indicated willingness to help Australia settle asylum seekers from its offshore detention policy, ${ }^{70}$ it is likely they would be willing to partake in a regional cooperative arrangement to resettle Rohingya refugees. There is undeniably a need for regional cooperation on the Rohingya refugee issue, and Australia is well placed to be able to take a leadership role in conjunction with ASEAN. This would not only help in the management of a humanitarian crisis but also serve to build a foundation of trust which would promote further cooperation in the future and subsequently open up alternative policy options on asylum seeker issues for the Australian government.

\section{Conclusions: Prospects for Australian- Led Regional Cooperation?}

As discussed at the beginning of the paper, Australia must play a leadership role on this issue for there to be any kind of comprehensive, multilateral regional

\footnotetext{
${ }^{70}$ Helen Davidson, “Turnbull Rejects New Zealand Offer to Take 150 Refugees From Detention", $\quad(29 \quad$ April 2016):https://www.theguardian.com/australi a-news/2016/apr/29/turnbull-rejects-newzealand-offer-to-take-150-refugees-fromdetention (accessed 21 October 2016).
}

cooperation on the issue of asylum seekers and refugees. Betts' three key points for promoting cooperation are all in play with Australia's interests extending beyond pure humanitarian concerns, a key individual in the form of upcoming Secretary-General Antonio Guterres, and there is potential to build trust in effective and reciprocal burden-sharing. Although it is apparent that the political will required to forge an alternative policy path on asylum seekers within the domestic political context will be difficult to find and even more difficult to follow through on, there is currently more promise and opportunity for such a change to take place than there has been since the issue once more began to dominate political debate.There are a number of different reasons for this. Firstly, both international and domestic critiques of the nature of human rights abuses involved in Australia's offshore detention programme have intensified. Although such critiques have been ongoing for some time now, it appears that they are having some degree of impact given Turnbull's decision to change the legislation regarding doctors and nurses speaking about the detention centres. ${ }^{71}$ Health professionals are now

\footnotetext{
${ }^{71}$ Bianca Hall, “'A Huge Win for Doctors': Turnbull Government Backs Down on Gag Laws for Doctors on Nauru and Manus", The Sydney Morning Herald (October 20
} 


\section{Sian Troath | Prospects for Australian-Led Regional Cooperation on Asylum Seeker and Refugee Issues}

exempt from 'the definition of "immigration and border protection workers", which removes them from the provisions regarding secrecy in the Border Force Act and means they no longer face two years jail time for discussing any abuses or negligence taking place in offshore detention centres. ${ }^{72}$ Bianca Hall argues that this change is likely prompted by the fact that the government was due to submit its defence against the case presented by the Fitzroy Legal Centre and Doctors for Refugees regarding the secrecy provisions. ${ }^{73} \mathrm{~A}$ negative finding from the High Court at this time would follow on from the highly publicised $\mathrm{ABC}$ Four Corners report on the issue, as well as the release of a major report on the treatment of detainees on Nauru by Amnesty International and the 2000 incident reports which were leaked in August. ${ }^{74}$ Clearly, humanitarian critiques of the offshore detention policy are beginning to take their toll. Secondly, the future of using Manus Island for offshore detention is in doubt following a determination by the Supreme Court of Papua New Guinea

2016):http://www.smh.com.au/federalpolitics/political-news/a-huge-win-fordoctors-turnbull-government-backs-downon-gag-laws-for-doctors-on-nauru-andmanus-20161019-gs6ecs.html(accessed October 20 2016).

72 Ibid.

${ }^{73}$ Ibid.

${ }^{74}$ Ibid. in April that the Regional Processing Centre on Manus Island was unconstitutional and had to be closed down. ${ }^{75}$ Although it was recently announced by Papua New Guinea Foreign Minister Rimbink Pato that only one of the two facilities on Manus Island is covered under the Supreme Court ruling, at the very least one facility is being closed down and the other one remains under fire from the Papua New Guinea Opposition. ${ }^{76}$ These two changes taken together indicate that the policy of offshore detention in its current form is weakening, although the domestic political demand for deterrencebased policies remains strong. This means that if the situation regarding claims of human rights abuses and the feasibility of continuing use of Manus Island as an offshore detention location continue to deteriorate, the government will be keen to seek a change in policy which can still be marketed as being tough on borders. The only way to achieve such a policy would be through regional cooperation.

What, then, are the prospects for regional cooperation? As argued above, a

\footnotetext{
${ }^{75}$ Author not specified, "Manus Island: PNG Government Under Fire from Opposition, Greens, After Keeping Asylum Facility Open", $\quad A B C \quad \operatorname{News}(5 \quad$ October 2016):http://www.abc.net.au/news/2016-1005/png-manus-detention-opposition-legaldecision/7906036(accessed 20 October 2016).

${ }^{76}$ Ibid.
} 


\section{Sian Troath | Prospects for Australian-Led Regional Cooperation on Asylum Seeker and Refugee Issues}

strong relationship with Indonesia is vital for regional cooperation to take place on asylum seeker and refugee issues. Many of the methods through which a bilateral relationship can be improved include more long-term approaches. In the case of Australia and Indonesia, one of the key methods would be increased education on each other, particularly on the Australian side both with regards to Indonesia as a country and society, as well as Indonesian language learning. This would come under the category of people-to-people relations, which are slowly being improved through increasing cultural and study exchange, such as that facilitated by the reverse Colombo Plan. However, there are also short-term improvements that can be made. One of these involves leader-toleader and government-to-government relations. Given the leadership change in Australia from the often contentious Tony Abbott to Malcolm Turnbull, there is certainly potential for improvement in this area. The contentiousness of Tony Abbott was not helped by the change in leadership in Indonesia in 2014 from the overtly internationalist Yudhoyono to the domestically-focused Joko Widodo. However, the recent announcement of President Widodo's planning to visit Australia in November following the positive start to their relationship during Turnbull's visit to Jakarta last year, certainly indicates that there is considerable potential for the relationship between the two leaders to develop. ${ }^{77}$ Jewel Topsfield argues that the announcement shows "a powerful indication of the warmth between the leaders of the two countries". ${ }^{78}$ While Topsfield argues that last year's visit was seen as a turning point in the relationship, ${ }^{79}$ Tim Lindsey goes on to claim that this year's visit will mark "a reset in the wake of Tony Abbott's departure from the prime ministership" ${ }^{80}$ Any influence Antonio Guterres could exude from his international platform would be much more effective if it were able to build on a strong relationship between Turnbull and Widodo. The influence of Antonio Guterres, improved relations between Turnbull and Widodo, and the ongoing disintegration of Australia's offshore detention policy,

\footnotetext{
${ }^{77}$ Jewel Topsfield, 'Indonesian President Joko Widodo to Visit Australia in November 2016', The Sydney Morning Herald (September 8 2016):http://www.smh.com.au/world/indone sian-president-joko-widodo-to-visitaustralia-in-november-2016-20160908grc3po.html(accessed 11 October 2016).

${ }^{78}$ Ibid.

${ }^{79}$ Ibid.

${ }^{80}$ Tim Lindsey, quoted in Naomi Woodley, 'Prime Minister Malcolm Turnbull's Visit Could 'Reset' Australia's Relationship with Indonesia', $A B C$ News (3 November 2015):www.abc.net.au/news/2015-1103/turnbull-could-reset-australia-indonesiarelations-experts-say/6906922(accessed 20 October 2016).
} 


\section{Sian Troath | Prospects for Australian-Led Regional Cooperation on Asylum Seeker and Refugee Issues}

provide the best opportunity for cooperation on asylum seekers that has been seen in recent years. If this could be channelled into cooperation on the resettlement of Rohingya asylum seekers, an issue which has every chance of escalating once more, then a building block for further cooperation could be established, paving the way to deeper, broader, and more sustained regional cooperation on asylum seeker and refugee issues.

\section{Bibliography:}

Author not specified, 'Abbott belittles Spying Row: SBY', The Jakarta Post (November 19 2013):

http://www.thejakartapost.com/ne ws/2013/11/19/abbott-belittlesspying-row-sby.html (accessed 28/02/2015).

Author not specified, 'Manus Island: PNG Government Under Fire from Opposition, Greens, After Keeping Asylum Facility Open', $A B C$ News (5 October 2016): http://www.abc.net.au/news/2016

-10-05/png-manus-detentionopposition-legaldecision/7906036 (accessed 20 October 2016).
Author not specified, 'Julia Gillard's Speech to the Lowy Institute on Labor's New Asylum-Seeker Policy for Australia', The Australian (July 7 2010): http://www.theaustralian.com.au/ archive/politics/julia-gillardsspeech-to-the-lowy-institute-onlabors-new-asylum-seeker-policyfor-australia/story-e6frgczf1225888445622

(accessed 28/02/2015).

Author not specified, "Who is Antonio Guterres? Meet the UN's Next Secretary-General', BBC News (6 October 2016):

www.bbc.com/news/worldeurope-37565570 (accessed 19 October 2016).

Bachelard, Michael, and Wroe, David, 'Indonesia Recalls Ambassador to Australia Over Spying Claim', The Age (November 18 2013): http://www.theage.com.au/world/i ndonesia-recalls-ambassador-toaustralia-over-spying-claim20131118-2xrem.html (accessed 28/02/2015).

Bateman, Sam, 'Maritime Confidence Building Measures - An Overview', in Maritime Confidence Building Measures in the South China Sea, ASPI 
Sian Troath | Prospects for Australian-Led Regional Cooperation on Asylum Seeker and Refugee Issues

Special Report (September 2013):

Refugees From Detention', (29

7-13.

April

2016):

Betts, Katharine, 'Boatpeople and Public

https://www.theguardian.com/aust

Opinion in Australia', People and ralia-news/2016/apr/29/turnbull-

Place 9, no. 4 (2001): 34-48.

rejects-new-zealand-offer-to-take-

Betts, Alexander. Protection by 150-refugees-from-detention

Persuasion: International (accessed 21 October 2016).

Cooperation in the Refugee

Regime.USA: Cornell University

Press, 2009.

Bourke, Latika, 'Navy Breached Indonesian waters Six Times Under Operation Sovereign Borders, Review Finds', $A B C$ News (20 February 2014): http://www.abc.net.au/news/2014 $-02-19 /$ navy-breachedindonesian-waters-six-timesreview-finds/5270478 (accessed 28/02/2015).

Burke, Anthony. Fear of Security: Australia's Invasion Anxiety.Melbourne: Cambridge University Press, 2008.

Chia, Joyce, and Justice Susan Kenny, 'The Children of Mae La: Reflections on Regional Refugee Cooperation', Melbourne Journal of International Law 13, no. 2 (2012): 838-359.

Davidson, Helen, 'Turnbull Rejects New Zealand Offer to Take 150

Davies, Matthew, 'Rohingya and Our Rule-Bending Arrogance', $A B C$ News: The Drum (18 May 2015): http://www.abc.net.au/news/2015 -05-18/davies-rohingya-and-ourrule-bending-arrogance/6477148 (accessed 20 October 2016).

Davies, Matthew, 'The Rohingya and Regional Failure', New Mandala: New Perspectives on Southeast Asia (16 May 2015): http://www.newmandala.org/therohingya-and-regional-failure/ (accessed 20 October 2016).

Della-Giacoma, Jim, 'Different Pond, Different Fish: Crossed Wires in Australian-Indonesian Relations', Kill Your Darlings 17 (2014): 825 .

Flitton, Daniel, 'Diplomat Rejects Abbott's Tow-Back Plan', The Sydney Morning Herald (October 24 2012):

http://www.smh.com.au/opinion/p olitical-news/diplomat-rejects- 
Sian Troath | Prospects for Australian-Led Regional Cooperation on Asylum Seeker and Refugee Issues

abbotts-towback-plan-20121023-

283hp.html\#ixzz2ADhYwtq7

(accessed 28/02/2015).

Grewcock, Michael, 'Australian Border Policing: Regional 'Solutions' and Neocolonialism', Race and Class 55, no. 3 (2014): 71-78.

Grewcock, Michael, 'Back to the Future: Australian Border Policing Under Labor, 2007-2013', State Crime Journal 3, no. 1 (2014): 102-125.

Griffiths, Emma, 'Indonesia Says Australia Alledgedly Adding Passenger to Asylum Seeker Boat a 'Serious Development", $A B C$ News (May 7 2014):

http://www.abc.net.au/news/2014

-05-06/marty-natalegawa-onboat-extra-passengers-seriousdevelopment/5434540 (accessed 28/02/2015)

Hall, Bianca, 'A Huge Win for Doctors': Turnbull Government Backs Down on Gag Laws for Doctors on Nauru and Manus', The Sydney Morning Herald(October 20 2016):

http://www.smh.com.au/federalpolitics/political-news/a-hugewin-for-doctors-turnbullgovernment-backs-down-on-gaglaws-for-doctors-on-nauru-and- manus-20161019-gs6ecs.html (accessed October 20 2016).

Hellendorff, Bruno, and Manuel Schmitz, 'Indonesia: From Regional to Global Power?',GRIP Analysis (7 May 2014): 1-20.

Hunt, Luke, 'Indonesia Watch', The Diplomat (May 17 2011): http://thediplomat.com/2011/05/in donesia-watch/ (accessed 28/02/2015).

Kevin, Tony, 'Mishandling Indonesia', Eureka Street 23, no. 22 (2013): 15-17.

Kneebone, Susan, 'Comparative Regional Protection Frameworks for Refugees: Norms and Norm Entrepreneurs', The International Journal of Human Rights 20, no. 2 (2016): 153-172.

Kneebone, Susan, and Sharon Pickering, 'Australia, Indonesia and the Pacific Plan', in New Regionalism an Asylum Seekers: Challenges Ahead, edited by Susan Kneebone and Felicity Rawlings-Sanei, 167188. Oxford and New York:Berghahn Books, 2007.

McDonald, Matt, 'Deliberation and Resecuritization: Australia, Asylum-Seekers and the Normative Limits of the 
Sian Troath | Prospects for Australian-Led Regional Cooperation on Asylum Seeker and Refugee Issues

Copenhagen School', Australian

Journal of Political Science 46, no. 2 (2011): 281-295.

McKay, Fiona H., 'A Return to the 'Pacific

Solution', Forced Migration

Review 44 (2013): 24-26.

McKay, Fiona. H., Samantha L. Thomas, and Warwick Blood, "Any One of These Boat People Could Be A Terrorist For All We Know!' Media Representations and Public Perceptions of 'Boat People' Arrivals in Australia', Journalism 12, no. 5 (2011): 607-626.

Nethery, Amy, Brynna Rafferty-Brown, and Savitri Taylor, 'Exporting Detention: Australia-Funded Immigration Detention in Indonesia', Journal of Refugee Studies 26, no. 1 (2012): 88-109.

Perera, Suvendrini, 'What is a Camp ... . ?',Borderlands E-journal 1, no. 1 (2002):

http://www.borderlands.net.au/vol 1no1_2002/perera_camp.html (accessed 28/02/2015).

Phillips, Janet, and Harriet Spinks, 'Boat Arrivals in Australia Since 1976', Australian Parliamentary Library (2013): 1-29.

Pickering, Sharon, and Leanne Weber, 'New Deterrence Scripts in Australia's Rejuvenated Offshore
Detention regime for Asylum Seekers', Law \& Social Inquiry 39, no. 4 (2014): 1006-1026.

Rowe, Elizabeth, and Erin O'Brien, "Genuine' Refugees or Illegitimate 'Boat People': Political Constructions of Asylum Seekers and Refugees in the Malaysia Deal Debate', Australian Journal of Social Science 49, no. 2 (2014) 171-193.

Slezak, Amanda Crews, Thalia Roussos Singer, and Rupa Ramadurai, 'Stateless and Fleeing Persecution: the Situation of the Rohingya in Thailand', Children's Legal Rights Journal 35, no. 1 (2015): 44-79.

Taylor, Savitri, 'Regional Cooperation and the Malaysian Solution', Inside Story (9 May 2011): http://insidestory.org.au/regionalcooperation-and-the-malaysiansolution/ (accessed 10 October 2016).

Taylor, Savitri, 'Sharing Responsibility for Asylum Seekers and Refugees in the Asia Pacific Region', in Migration: The Ashgate Research Companion to Migration Law, Theory and Policy, edited by Satvinder S. Juss, 233- 
Sian Troath | Prospects for Australian-Led Regional Cooperation on Asylum Seeker and Refugee Issues

266.Surrey: Ashgate Publishing with Indonesia', $A B C$ News (3 Limited, 2013.

November 2015):

Taylor, Savitri, and Brynna Rafferty-

Brown, 'Waiting for Life to

Begin: the Plight of Asylum

Seekers Caught by Australia's

Indonesian Solution',

www.abc.net.au/news/2015-11-

03/turnbull-could-reset-australiaindonesia-relations-expertssay/6906922 (accessed 20 October 2016).

International Journal of Refugee Law 22, no. 4 (2010): 558-592.

Thayer, Carlyle. A., 'Southeast Asia's Regional Autonomy Under Woolner, Derek, 'When No Means No: Indonesia and Tony Abbott's Asylum Boat Policy', Dissent Stress', Southeast Asian Affairs (2016).

Topsfield, Jewel, 'Indonesian President Joko Widodo to Visit Australia in November 2016', The Sydney Morning Herald (September 8 2016):

http://www.smh.com.au/world/in donesian-president-joko-widodoto-visit-australia-in-november2016-20160908-grc3po.html (accessed 11 October 2016).

White, Christopher C., 'Australia's Boatpeople Policy: Regional Cooperation or Passing the Buck?",Cultural Encounters, Conflicts, and Resolutions 1, no. 1 (2014): 1-21.

Woodley, Naomi, 'Prime Minister Malcolm Turnbull's Visit Could 'Reset' Australia's Relationship 